\title{
Exploration of some important fodder plants of Joshimath area of Chamoli district of Garhwal, Uttarakhand
}

\author{
Meena Nautiyal ${ }^{1 *}$, J. K. Tiwari ${ }^{1}$, Dinesh Singh Rawat ${ }^{2}$ \\ ${ }^{1}$ Department of Botany and Microbiology, HNB Garhwal University, Srinagar, Garhwal, Uttarakhand, India, ${ }^{2}$ Central National \\ Herbarium, Botanical Survey of India, Howrah, West Bengal, India
}

Received: 26.06 .2017
Accepted: 28.08.2017
Published: 30.08 .2017
*Address for
correspondence:
Meena Nautiyal, Department
of Botany and Microbiology,
HNB Garhwal University,
Srinagar, Garhwal - 246 174,
Uttarakhand, India.
E-mail: meenunautiyal89@
gmail.com

gmail.com

\begin{abstract}
India has more than $13 \%$ of the total livestock population of the world, but it does not have specially identified and regularly managed pastures. Although about 12 million ha of the land in the country is officially recorded as the grazing land, a vast majority of the population depends on the forest for fodder. Livestock is considered as one of the main sources of livelihood, which depends mostly on fodder. Fodder is extracted from forests, grasslands, agricultural land, and agroforestry practices. Agriculture with animal husbandry is the main profession of rural people of this Himalayan region. Livestock plays an important role in the economy of Uttarakhand as it is the important source of income of rural people. There is a vast diversity of fodder plants. Demand for fodder is uniform throughout the year although unavailability of green forage during winter has always remained a serious issue resulting into nutritional deficiency in milching animals. Thus, there is a need to explore fodder plants in Garhwal Himalayas. The present study was conducted to find the diversity of fodder plants and their seasonal availability and mode of use in Chamoli district. The study covers some villages of Joshimath area of Chamoli district of Garhwal which lie in between $30^{\circ} 26^{\prime} 52.37^{\prime \prime}$ to $30^{\circ} 33^{\prime} 02.52^{\prime \prime} N$ latitude and $79^{\circ} 33^{\prime} 57.56^{\prime \prime}$ to $79^{\circ} 41^{\prime} 34.79^{\prime \prime} \mathrm{E}$ longitude. The survey was conducted in the years 2014 and 2015. Information on locality, mode of use, and seasonal availability was recorded by interviewing the people of the studied villages. The findings recorded 89 fodder species representing trees, shrubs, herbs, grasses, and climbers. During the rainy season, the availability of fodder is in plenty, but there is fodder crisis in other seasons of the year as people are not aware of scientific conservation of grasses for lean periods. It was observed that more fodder species are needed to be planted to increase the fodder availability in the area.
\end{abstract}

KEY WORDS: Fodder plants, Garhwal Himalayas, seasonal availability

\section{INTRODUCTION}

The Indian Himalayan Region, including Himalayas proper and the north-eastern states, lies in between $21^{\circ} 57^{\prime}$ to $37^{\circ} 5^{\prime} \mathrm{N}$ latitudes and $72^{\circ} 40^{\prime}$ to $97^{\circ} 45^{\prime} \mathrm{E}$ longitudes. It stretches over $2500 \mathrm{~km}$ from Jammu and Kashmir in the west to Arunachal Pradesh in the east. Himalayas, one of the richest hot spots of biodiversity of the globe, offers immense opportunities in various biological domains and associated patterns of sustainable life support system. It is well known for its diverse range of habitats, species populations, communities, and ecosystems. It is divided into Western, Central, and Eastern zones (Valdia and Bhatia, 1980). Uttarakhand is one of the important states of Indian Himalayan Region. Garhwal Himalayas along with
Kumaon Himalayas constitutes the North-West Himalaya. A number of forest types occur in the Himalayas, which are distributed widely with the gradients of elevation ranging from subtropical to temperate and alpine zones (Champion and Seth, 1968; Singh and Singh, 1987; 1992). The inhabitants residing in this region use plant resources for food, medicine, fuel, house construction, religious activities, and various other purposes; the extraction of fodder is one of them.

Conventionally, forests have been considered important natural resource because of their economic value as providers of fuel, fodder and timber, ecological value for water-soil conservation, and control of landslides. More than $50 \%$ of the fodder for ruminant animals 
come from forest resources (Kadariya, 1992). Livestock is the main component of the mixed farming system in the Himalayan region. Inhabitants convert the energy of forests, grasslands, and crop residues into useful products such as draught power, milk, meat, wool, and manure.

Fodder generally refers to food given to the animals consisting mainly the plant parts. Fodder includes hay, strains, silage, compressed and paletted feeds, oils and mixed rations and sprouted grains and legumes. The fodder contains nutritional components such as crude protein, fat, fiber, carbohydrates, and minerals (ash). Nutrient contents are fairly high in fodder tree species; however, their amount differs noticeably from one species to another (Mahato and Subba, 1998). In the Himalayas, up to 87\% of the fodder requirement is met by the forest (Pandey and Singh, 1984).

Fodder trees from forests, pastures, and agricultural lands play major role to meet the deficiency of animal feeds. Fodder collected from the forest (ground herbage and tree leaves) forms the largest component of biomass energy, which plays a significant role in improving the nutritional requirement of livestock. Fodder tree leaves contain higher protein and calcium compared to grasses and straws (Rana et al., 1999). The major reason of low productivity of the livestock is insufficient, low quality feeds and fodders, especially during the dry season (Tulachan and Neupane, 1999; Keftara, 1994).

Tree leaves are alternative feed source for ruminant (Malik et al., 1967) and can help to minimize the wide gap between availability and supply of nutrients and improve the animal growth and productivity. Fodder tree leaves were found to be rich in protein, soluble carbohydrates, minerals, and vitamins and showed great potential as an alternate feed resource (Baumer, 1992; Bakshi and Wadhwa, 2007). Use of tree leaves in ruminant enhances microbial growth and digestion (Bonsi et al., 1995). However, efforts to minimize the cost of mineral supplementation in livestock production require a thorough knowledge of the supply and availability of mineral nutrients in feed and forages.

Quantity and quality of ruminants feed availability depends on the seasons, elevation and aspects of mountains. Evergreen trees are a major feed source for animals in Uttarakhand; however, lack of feed is the major factor limiting the animal productivity for dry periods of 9 months from October to June. Trees growing in the open forest and road sides are generally lopped by the grazers. The primary role being played by a fodder tree is to produce green and fresh foliage during the period of the dry season when there is no other alternative green feed available. By planting tree fodder, many other benefits are created which can last for many years; they include conservation of soil, fuelwood, windbreaks, fiber production shade, and increase in the biodiversity.

Several species of fodder-yielding plants including herbaceous plants, trees, and shrubs are present in the submontane and montane zones in the mountains of Uttarakhand Himalayas. A few studies have been conducted on fodder resources in the Uttarakhand Himalayas by Anonymous (1982), Jackson (1985), Bhatt and Rawat (1993), Singh $(1985 ; 1989 ; 2002 ; 2005)$, Jodha and Shrestha (1990), Singh and Bohra (2005), Singh and Gaur (2005), Bohra (2006), and Singh et al. (2008). In the present paper, attempts have, therefore, been made to enlist plant species which are commonly used for cattle growing in the area.

\section{MATERIALS AND METHODS}

Joshimath is one of the hilly areas of Chamoli districts of Uttarakhand state. The area lies in between $30^{\circ} 26^{\prime} 52.37^{\prime \prime}$ to $30^{\circ} 33^{\prime} 02.52^{\prime \prime} \mathrm{N}$ latitude and $79^{\circ} 33^{\prime} 57.56^{\prime \prime}$ to $89^{\circ} 41^{\prime} 34.79^{\prime \prime} \mathrm{E}$ longitude. The study was carried out in some villages of Joshimath area of Chamoli district. The climate in the study area can be divided into three distinct seasons, cool and relatively dry winter (November to March), warm and dry summer (mid-April to June) and rainy (July to mid-September).

The study was conducted by means of community-based questionnaire. The survey was conducted during the years 2014 and 2015. For collection of fodder specimens, frequent field trips were made during different seasons of the years. For this, villages such as Mirag, Raigadi, Tapovan, Karchi, Baragaon, Tugasi, Karchoon, Raini, and Dhak were visited. Information regarding locality, seasonal availability, and mode of use was also recorded by interviewing the villagers, elderly people, and shepherds of these villages. The collected plant specimens were identified with the help of regional floras and herbaria (BSD, DD, and GUH).

\section{RESULTS}

\section{Diversity}

In the present study, 89 plant species of fodder under 71 genera belonging to 38 families have been identified. Among the families, maximum species were represented from Poaceae (11 spp.) followed by Rosaceae (7 spp.), Urticaceae (6 spp.), Polygonaceae (5 spp.), Asteraceae and Salicaceae (5 spp. each). Poaceae is the dominant family 
with 11 genera followed by Urticaceae (6 genera), Rosaceae (5 genera), and Asteraceae (4 genera) (Figure 1). Species richness was highest in the genus Salix (3 spp.), followed by Chenopodium, Chrysopogon, Desmodium, Euonymus, Fagopyrum, Ficus, Rubus and Prunus (2 spp. each), Boehmeria, Amaranthus, Aesculus, Betula, Astilbe and Carpinus (1 spp. each).

Out of 89 fodder species, 26 species were trees, 21 shrubs, 39 herbs, and 3 species were climbers (Figure 2).

\section{Seasonal Availability}

The utilization pattern of fodder species varied from season to season. This variation in utilization pattern is due to the availability of species in respective seasons. Majority of the tree fodder species were used in summer due to availability of deciduous species while some tree species are also used in winter due to evergreen. Rainy season helps to produce plenty of green grasses and other herbaceous plants which are used as fodder. Out of 89 species, 15 species were used in summer, 12 in winter, 31 in rainy, and 12 in all the three seasons (Figure 3). Seven species made their use in both summer and winter while 8 in summer and rainy seasons. Quercus semecarpifolia, Miscanthus nepalensis, Pennisetum orientale, and Phoebe lanceolata are the major fodders, which are lopped during winter season. Celtis australis, Morus serrata, Acer spp., Ficus spp., Ulmus wallichiana, and Corylus jacquemontii are the main fodder trees that are lopped during summer. Dry fodders (crop residues and hay) are often fed to livestock in the winter season. Shrubs are chiefly browsed by goats and sheep, and leaves of Rubus niveus and Prinsepia utilis were fed to these. Among the recorded species, 77 species were used as green and remaining species were used both as green and dry. Plant species such as Setaria pumila, Galinsoga parviflora, Chrysopogon fulvus, Rubia manjith, Polypogon fugax, Boehmeria macrophylla, and Heteropogon contortus were used both as green and dry in the studied area (Table 1).

\section{DISCUSSION}

There are seasonal variations in fodder availability. In rainy season, fodder is abundant but becomes scarce in the dry season. Due to abundant fodder availability in the rainy season, cattle attain a healthy look and gain weight. It is becoming hard to find fodder for cattle because of reductions in grazing areas. In the present study, 89 plant species of fodder belonging to 40 families and 71 genera have been reported. Samant et al. (2007) listed 150 species of fodder representing trees, shrubs, and herbs used as fodder for livestock in the Indian Himalayan Region; some of the species are similar with that of our findings. The

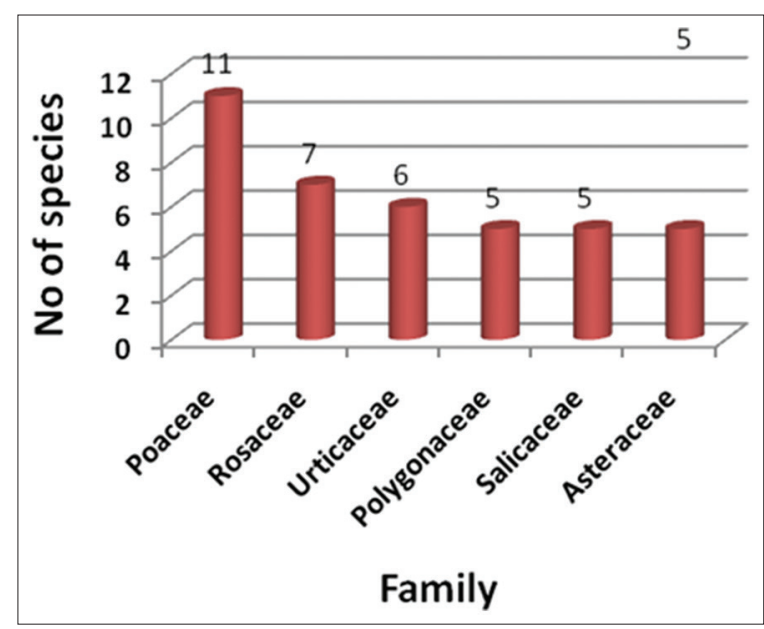

Figure 1: Dominant families of the study area

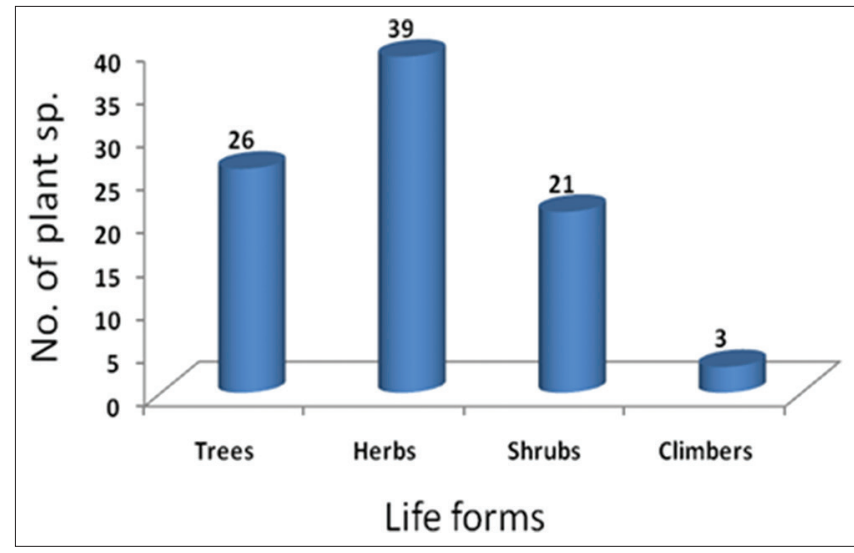

Figure 2: Diversity of fodder plants in different life forms

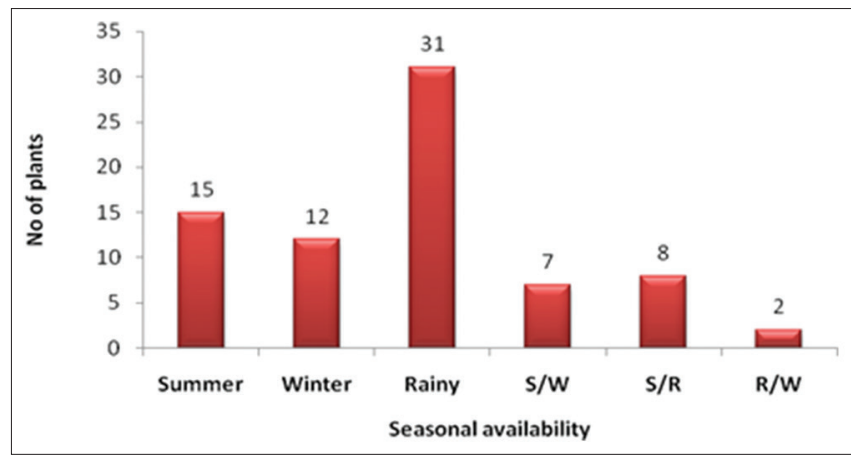

Figure 3: Seasonal availability of fodder plants

practice of farmers harvesting the fodder and transporting it as head loads to their houses and using the fodder in fresh or dry forms agrees with the findings of Gali et al. (2006) from Argentina. Uses of fodder in fresh and dry conditions have also been reported by Singh et al. (2008). Some plants like, Amranthus. viridis, Desmodium. laxiflorum, Ficus. hederacea, F. sarmentosa, Heteropogon contortus, Ilex dipyrena, Justicia simplex and Polypogon fugax, are used as fodder for all the season when no alternative is available. This is confirm 
Table 1: Diversity, seasonal availability, and mode of use of some fodder plants

\begin{tabular}{|c|c|c|c|c|c|}
\hline Species name & Local name & Family & Life form* & $\begin{array}{l}\text { Seasonal } \\
\text { availability** }\end{array}$ & Mode of use $e^{* * *}$ \\
\hline Acer acuminatum Wallich ex D.Don & Til-kanjul & Aceraceae & $\mathrm{T}$ & $\mathrm{R}$ & G \\
\hline Acer caesium Wallich ex Brandis & Kanjul & Aceraceae & $\mathrm{T}$ & $\mathrm{R}$ & G \\
\hline Aesculus indica & Pangar & Hippocastanaceae & $\mathrm{T}$ & $\mathrm{R}$ & G \\
\hline Amaranthus viridis $\mathrm{L}$. & Chaulai & Amaranthaceae & $\mathrm{H}$ & A & G \\
\hline Anemone vitifolia Buch-Ham. ex DC. & & Ranunculaceae & $\mathrm{H}$ & $\mathrm{R}$ & G \\
\hline Artemisia nilagirica & Kunjaa & Asteraceae & $\mathrm{S}$ & $\mathrm{S}$ & G \\
\hline Astilbe rivularis Buch-Ham. ex D.Don & & Saxifragaceae & S & $\mathrm{R}$ & G \\
\hline Betula alnoides Buch-Ham. ex D.Don & Kathbhuj & Betulaceae & $\mathrm{T}$ & S & G \\
\hline Boehmeria macrophylla D.Don & & Urticaceae & $\mathrm{S}$ & S/W & G/D \\
\hline Carpinus viminea Lindley & Cham-kharik & Corylaceae & $\mathrm{T}$ & S/W & G \\
\hline Celtis australis Hook. $\mathrm{f}$. & Kharik & Ulmaceae & $\mathrm{T}$ & S & G \\
\hline Chenopodium album $\mathrm{L}$. & Bathua & Chenopodiaceae & $\mathrm{H}$ & $\mathrm{S}$ & G \\
\hline Chenopodium botrys L. & & Chenopodiaceae & $\mathrm{H}$ & $S / R$ & G \\
\hline Chrysopogon fulvus Chiovenda & & Poaceae & $\mathrm{H}$ & S/W & G/D \\
\hline Chrysopogon gryllus Trinius & & Poaceae & $\mathrm{H}$ & $\mathrm{R}$ & G \\
\hline Commelina benghalensis L. & & Commelinaceae & $\mathrm{H}$ & $\mathrm{R}$ & G \\
\hline Corylus jacquemontii Decne. & Kabasi/Bhotia badam & Betulaceae & $\mathrm{T}$ & S & G \\
\hline Cynodon dactylon Persoon & Dubla & Poaceae & $\mathrm{H}$ & $\mathrm{S}$ & G \\
\hline Desmodium elegans DC. & Chamla & Fabaceae & $\mathrm{S}$ & $\mathrm{R}$ & G \\
\hline Desmodium laxiflorum DC. & & Fabaceae & $\mathrm{S}$ & A & G \\
\hline Dodecadenia grandiflora Nees & & Lauraceae & $\mathrm{T}$ & $\mathrm{S}$ & G \\
\hline Echinochloa crus-galli P. Beauv. & Jhavara ghas & Poaceae & $\mathrm{H}$ & $\mathrm{R}$ & G \\
\hline Eleusine coracana Gaertner & Mandua & Poaceae & $\mathrm{H}$ & W & D \\
\hline Euonymus pendulus Wallich & & Celastraceae & $\mathrm{T}$ & S/W & G \\
\hline Euonymus tingens Wallich & & Celastraceae & $\mathrm{T}$ & S & G \\
\hline Eurya acuminata DC. & & Theaceae & T & W & G \\
\hline Fagopyrum dibotrys Hara & Kanaya & Polygonaceae & $\mathrm{H}$ & $\mathrm{R}$ & G \\
\hline Fagopyrum esculentum Moench & Ougal & Polygonaceae & $\mathrm{H}$ & $S / R$ & G \\
\hline Ficus hederacea Roxb. & & Moraceae & S & A & G \\
\hline Ficus sarmentosa Buch.-Ham. ex J.E. Smith & & Moraceae & $\mathrm{S}$ & A & G \\
\hline Galinsoga parviflora Cav. & Banglya/Angeraji ghas & Asteraceae & $\mathrm{H}$ & $\mathrm{R} / \mathrm{W}$ & G/D \\
\hline Galium elegans Wallich & & Rubiaceae & $\mathrm{H}$ & $S / R$ & G \\
\hline Geranium wallichianum D.Don ex Sweet & & Geraniaceae & $\mathrm{H}$ & $\mathrm{R}$ & G \\
\hline Girardinia diversifolia Friis & & Urticaceae & $\mathrm{H}$ & W & D \\
\hline Hedera nepalensis K. Koch & & Araliaceae & C & $S / R$ & G \\
\hline $\begin{array}{l}\text { Heteropogon contortus P. Beauv. ex Roemer } \\
\text { and Schultes }\end{array}$ & & Poaceae & $\mathrm{H}$ & A & $G / D$ \\
\hline Hypericum choisianum Wallich ex N. Robson & & Hypericaceae & $\mathrm{S}$ & $\mathrm{S}$ & G \\
\hline Hypericum elodeoides Choisy & & Hypericaceae & $\mathrm{H}$ & $\mathrm{R}$ & G \\
\hline Ilex dipyrena Wallich & & Aquifoliaceae & $\mathrm{T}$ & A & G \\
\hline Impatiens scabrida DC. & & Balsamiaceae & $\mathrm{H}$ & $\mathrm{R}$ & G \\
\hline Impatiens balsamina $\mathrm{L}$. & Mangrya & Balsamiaceae & $\mathrm{H}$ & $\mathrm{R}$ & G \\
\hline Indigofera heterantha Wallich ex Brandis & Sakina & Papilionaceae & $\mathrm{S}$ & $\mathrm{R}$ & G \\
\hline Justicia simplex Yamazaki & & Acanthaceae & $\mathrm{H}$ & A & G \\
\hline Lonicera quinquelocularis Hardwicke & & Caprifoliaceae & $\mathrm{S}$ & S/W & G \\
\hline Maoutia puya Wedd & & Urticaceae & $\mathrm{S}$ & $\mathrm{R}$ & G \\
\hline Meliosma dilleniifolia Walpers & & Sabiaceae & $\mathrm{T}$ & A & G \\
\hline Miscanthus nepalensis Hackel & Dab & Poaceae & $\mathrm{H}$ & W & G \\
\hline Morus serrata Roxb. & Kaimu & Moraceae & $\mathrm{T}$ & $\mathrm{S}$ & G \\
\hline Neolitsea cuipala Kostermans & & Lauraceae & $\mathrm{T}$ & W & G \\
\hline Nicandra physalodes Gaertner & Datura & Solanaceae & $\mathrm{H}$ & $\mathrm{R}$ & $G$ \\
\hline Oxalis corniculata L. & & Oxalidaceae & $\mathrm{H}$ & A & G/D \\
\hline Pennisetum orientale L. & Musaya & Poaceae & $\mathrm{H}$ & W & G/D \\
\hline Persicaria capitata H.Gross & Rangaya & Polygonaceae & $\mathrm{H}$ & $\mathrm{R}$ & G \\
\hline Phoebe lanceolata Nees & & Lauraceae & $\mathrm{T}$ & W & G \\
\hline Pilea scripta Wedd. & Chau & Urticaceae & $\mathrm{H}$ & $\mathrm{R}$ & $G$ \\
\hline Pimpinella achilleifolia C.B. Clarke & & Apiaceae & $\mathrm{H}$ & $\mathrm{R}$ & G \\
\hline Pimpinella acuminata C.B. Clarke & & Apiaceae & $\mathrm{H}$ & $\mathrm{R}$ & G \\
\hline Polygonum amplexicaule D.Don & & Polygonaceae & $\mathrm{H}$ & $\mathrm{R}$ & G \\
\hline Polygonum capitatum Buch.-Ham. ex D.Don & & Polygonaceae & $\mathrm{H}$ & $\mathrm{S}$ & G \\
\hline Polypogon fugax Nees ex Steudel & & Poaceae & $\mathrm{H}$ & A & G/D \\
\hline Populus ciliata Wallich ex Royle & & Salicaceae & $\mathrm{T}$ & $\mathrm{R}$ & G \\
\hline Pouzolzia zeylanica J. Bennett and Brown & & Urticaceae & $\mathrm{H}$ & $\mathrm{R}$ & G \\
\hline Prinsepia utilis Royle & Bhainkal & Rosaceae & $\mathrm{S}$ & $\mathrm{R}$ & G \\
\hline
\end{tabular}


Table 1: (Continued)

\begin{tabular}{|c|c|c|c|c|c|}
\hline Species name & Local name & Family & Life form* & $\begin{array}{l}\text { Seasonal } \\
\text { availability** }\end{array}$ & Mode of use ${ }^{* * *}$ \\
\hline Prunus armeniaca L. & Chulu & Rosaceae & $\mathrm{T}$ & W & $G$ \\
\hline Prunus cornuta Steudel & & Rosaceae & $\mathrm{T}$ & S & G \\
\hline Pyrus pashia Buch.-Ham. ex D.Don & Melu & Rosaceae & $\mathrm{T}$ & $\mathrm{S}$ & G \\
\hline Quercus semecarpifolia J.E. Smith & Kharsu & Fagaceae & $\mathrm{T}$ & W & G \\
\hline Rubia manjith Roxb. ex Fleming & & Rubiaceae & C & W & $G / D$ \\
\hline Rubus niveus Thunb. & & Rosaceae & $\mathrm{S}$ & A & $G$ \\
\hline Rubus paniculatus Smith & & Rosaceae & $\mathrm{S}$ & $A$ & G \\
\hline Salix adenophylla Boissier & Gad-bhains & Salicaceae & $\mathrm{S}$ & $A$ & G \\
\hline Salix denticulata Anderson & & Salicaceae & $\mathrm{T}$ & S & G \\
\hline Salix tetrasperma Roxb. & & Salicaceae & $\mathrm{T}$ & S/W & G \\
\hline Scurrula elata Danser & & Loranthaceae & $\mathrm{S}$ & $\mathrm{R}$ & G \\
\hline Setaria pumila Roemer and Schultes & & Poaceae & $\mathrm{H}$ & $\mathrm{R}$ & $G / D$ \\
\hline Smilax glaucophylla Klotzsch & Kukurdara & Smilacaceae & C & $\mathrm{S} / \mathrm{R}$ & $G$ \\
\hline Solanum nigrum L. & Makoi & Solanaceae & $\mathrm{H}$ & $S / R$ & G \\
\hline Spiraea canescens D. Don & Mairad & Rosaceae & S & $\mathrm{R} / \mathrm{W}$ & G \\
\hline Swida oblonga Sojak & & Cornaceae & $\mathrm{T}$ & $\mathrm{R}$ & G \\
\hline Symplocos paniculata Miq. & & Symplocaceae & $\mathrm{T}$ & $S / R$ & $G$ \\
\hline Symplocos ramosissima Wallich ex G. Don & & Symplocaceae & $\mathrm{S}$ & $\mathrm{S} / \mathrm{R}$ & G \\
\hline Senecio rufinervis DC. & Phar patti & Asteraceae & $\mathrm{H}$ & W & G \\
\hline Taraxacum officinale Weber & & Asteraceae & $\mathrm{H}$ & $\mathrm{R}$ & G \\
\hline Thalictrum foliolosum DC. & & Ranunculaceae & $\mathrm{H}$ & $\mathrm{R}$ & G \\
\hline Thamnocalamus falconeri Hook.f. ex Munro & Ringal & Poaceae & $\mathrm{S}$ & S/W & G \\
\hline Ulmus wallichiana Planchon & Mairu & Ulmaceae & $\mathrm{T}$ & $\mathrm{S}$ & G \\
\hline Urtica dioica L. & Kandali & Urticaceae & S & W & G \\
\hline Viburnum erubescens Wallich ex DC. & Teeling & Caprifoliaceae & $\mathrm{S}$ & $\mathrm{R}$ & G \\
\hline Vigna vexillata $\mathrm{A}$. Richard & & Fabaceae & $\mathrm{H}$ & $A$ & $G / D$ \\
\hline
\end{tabular}

*T: Tree, H: Herb, C: Climber, S: Shrub, **S: Summer, W: Winter, R: Rainy, A: All the three seasons, ***G: Green, D: Dry

with the findings of Gherobin et al. (2007) who observed that warm season grasses and legumes have the potential to provide forage throught the miditerranean summer where there were high temperature and low rainfall and when cool seasonal grasses becomes less productive. On the whole, there is a shortage of fodder in the study area.

\section{ACKNOWLEDGMENT}

The authors thank and acknowledge the people of the study area for providing valuable information. We are also grateful to UGC for providing financial assistance.

\section{REFERENCES}

Anonymous. Integrated Natural Human Resources Planning and Management in the Hills of U.P. Pantnagar: GB Pant University; 1982.

Bakshi MP, Wadhwa M. Tree leaves as complete feed for goat kids. Small Rumin Res 2007;69:74-8.

Baumer M. Trees as browse and to support animal production. In: Speedy A, Pugliese PL, editors. LegumeTrees and Other FodderTrees as Protein Sources for Livestock. FAO Animal Production and Health Paper No. 102. Rome, Italy: FAO; 1992. p. 1-10.

Bhatt AB, Rawat N. Fodder resources of Garhwal: A search for non-conventional fodder species. In: Rajwar GS, editor. Garhwal Himalaya: Ecology and Environment. New Delhi:
Ashish Publishing House; 1993. p. 227-39.

Bohra B. Dairy Farming and Rangeland Resources in Mountain Agro-Ecosystems in Uttaranchal. PhD. Thesis. GB Pant University of Agriculture andTechnology, Pantnagar; 2006.

Bonsi ML, Osuji PO, Thuah AK. Effect of supplementing tef straw with different levels of Leucaena or Sasbania on the degradability of tef straw, Sesbania, Leucaena, Tageles and Vernonia and certain rumen and blood metabolities in Ethopian menz sheep. Anim Feed Sci Technol 1995;52:101-29.

Champion HG, Seth SK. A Revised Survey of Forest Types of India. Delhi: Govt. of India Publication; 1968.

Galli JR, Cangiano CA, Demment MW, Laca EA. Acoustic monitoring of chewing and intake of fresh and dry forages in steers Anim. Feed Sci Technol 2006;128(1-2):14-30.

Jackson MG. A strategy for improving productivity of livestock in the hills of Uttar Pradesh. In: Singh JS, editor. Environmental Regeneration in Himalaya: Concepts and Strategies. Nainital: Gyanodaya Prakashan; 1985.

Jodha NS, Shrestha S. Some Conceptual Issues of Livestock Farming in the Mountains. Mountain Farming Systems Discussion Paper No. 4. Kathmandu: ICIMOD; 1990.

Kadariya RK. The Development of Sustainable Livestock Production Systems in the Mid Hills of Nepal, Based Upon Agro Forestry Concepts. Paper Presented at LARC Seminar. Nepal: Lumle Agriculture Research Centre (LARC) Pokhara; 1992. 
Keftara D. Integration of livestock and crop production. Training notes for sixth Hohenheim legume course "Legumes in cropping system of the tropics and subtropics. Germany: Tropical Centre, Hohenheim University; 1994.

Mahato SN, Subba DB. Chemical Composition and Nutritive Values of Feeds of East Nepal. Dhankuta, Nepal: Pakribas Agricultural Centre; 1998.

Malik MY, Sheikh AA, Shah WH. Chemical composition of indigenous fodder tree leaves. Pak J Sci 1967;19:5-7.

Pandey U, Singh JS. Energy-flow relationships between agro system and forest ecosystems in Central Himalaya. Environ Conserv 1984;11:45-53.

Rana RS, Yano F, Khanal SK, Pandey SB. Crude Protein and Mineral Content of Some Major Fodder Trees of Nepal. Lumle Seminar Paper No. 99/13. Nepal: Lumle Agriculture Research Center; 1999.

Samant SS, Singh M, Lal M, Pant S. Diversity, distribution and prioritization of fodder species for conservation in Kullu District, Northwestern Himalaya, India. Journal of Mountain Science 2007;4(3):259-274.

Singh JS, Singh SP. Forest vegetation of central Himalya. Bot Rev 1987;53:82-192.

Singh JS, Singh SP. Forests of Himalaya. Nainital, India: Gyanodaya Prakkashan; 1992.

SinghV, Bohra B. Dairy Farming in Mountain Areas. New Delhi: Daya Publishers; 2005.

Singh V, Gaur RD, Bohra B. A survey of fodder plants in midaltitude Himalayan rangelands of Uttarakhand, India. J Mt Sci 2008;5:265-78.

SinghV, Gaur RD. The Himalayan rangelands ecosystem services and ecotourism opportunities. In: Rajwar GS, Bisht H, Sharma YK, Kushwaha MD, Goswami DC, Rawat MS, editors. Tourism and Himalayan Biodiversity: Souvenir and Abstracts. Uttarkashi: Govt. PG College; 2005.

Singh V. Animal Draoght Power and Fodder Resources at Midaltitude Himalayan Villages. PhD. Thesis. Pantnagar: GB Pant University of Agriculture and Technology; 1985.

Singh V. Dairy development vis-à-vis agro-ecosystems in Himalayan mountains: Perspective, issues and strategies in Uttarakhand, India. In: Rowlinson P, Wachirapakorn C, Pakdee P, Wanapat M, editors. Intergating Livestock-Crop Systems to Meet the Challenges of Globalisation. Vol. 2. London: British Society of Animal Science; 2005.

Singh V. Improving the productivity of forest/grassland-based farming systems in the UP Hills. Adv Forest Res India 1989;3:157-76.

Singh V. Smallholder dairy farming in Uttarakhand, India: Characteristics, constraints and development opportunities. In: Tulachan PM, Jabbar MA, Saleem MA, editors. Smallholder Dairy Farming in Mixed Farming Systems of Hindu-Kush-Himalayan Regions. Kathmandu: ICIMOD; 2002. p. 53-70.

Tulachan PM, Neupane A. Livestock in Mixed Farming Systems of Hindu Kush-Himalayas: Trends and Sustainability. Kathmandu: Nepal International Center for Integrated Mountain Development (ICIMOD); 1999.

Valdia KS, Bhatia SB. Stratigraphy and Correlation of Lesser Himalayan Formations. Delhi: Hindustan Publication Corp; 1980. 